\title{
To What Cost to its Continental Hegemonic Standpoint: Making Sense of South Africa's Xenophobia Conundrum Post Democratization
}

\author{
Daniel N. Mlambo ${ }^{1}$ \\ Tshwane University of Technology, South Africa \\ Victor H. Mlambo \\ University of Zululand, South Africa
}

\begin{abstract}
From the 1940s, a period where the National Party (NP) came into power and destabilized African and Southern Africa's political dynamics, South Africa became a pariah state and isolated from both the African and African political realms and, to some extent, global spectrum(s). The domestic political transition period (1990-1994) from apartheid to democracy further changed Pretoria's continental political stance. After the first-ever democratic elections in 1994, where the African National Congress (ANC) was victorious, South Africa was regarded as a regional and continental hegemon capable of re-uniting itself with continental and global politics and importantly uniting African states because of its relatively robust economy. However, the demise of apartheid brought immense opportunities for other African migrants to come and settle in South Africa for diverse reasons and bring a new enemy in xenophobia. Post-1994, xenophobia has rattled South Africa driven (albeit not entirely) by escalating domestic social ills and foreign nationals often being blamed for this. Using a qualitative methodology supplemented by secondary data, this article ponders xenophobia in post-democratization South Africa and what setbacks this has had on its hegemonic standpoint in Africa post the apartheid era.
\end{abstract}

Keywords: African National Congress, Hegemony, Migrants, South Africa, Xenophobia.

In the past few decades and particularly the post-colonial era, scholars have made rigorous Afrocentric attempts to examine the drivers, repercussions, and remedies of recurring xenophobic attacks, particularly in South Africa (Charman \& Piper, 2012; Chenzi, 2020; Everatt, 2011; Steenkamp, 2009; Tella, 2016). This has stemmed from the fact that xenophobia of other African nationals has continued to rise over the years, particularly in countries with relatively robust economies, infrastructure and deemed politically stable. These are countries that Gramsci (1971)) refers to as hegemonic states ${ }^{2}$ in his Prison Notebooks (1925-1935) and are referred to as modern economies in their specific regions. Similarly, regional powers or

\footnotetext{
${ }^{1}$ Corresponding Author E-Mail: mlambo1@ymail.com

${ }^{2}$ As a concept, hegemony has enjoyed immense scholarly attention although it commonly evokes negative images of a bully and domineering state that imposes its will on weaker states. This narrative situates power from the purview of the possession of superior material capabilities of military, economic, provision of public goods and demographic strengths (Gramsci, 1971; Ogunnubi, 2019). Furthermore, hegemony implies the ability of the hegemon to have subordinates believe that power rests upon the consensus of the majority, thus, the hegemon possess public goods that can be of benefit to the weaker regional members.
} 
hegemons have been defined by literature around a core of constitutive features including but not limited to 1) belonging to a given region, 2) possessing material capabilities superior to the rest of the region, and 3) exerting some kind of influence over the region (see Mesquita \& Seabra, 2020). From the 1960s to the late 1990s, South Africa was often denoted as a pariah state isolated from the continental and international political landscape. This was driven by the apartheid regime's destabilization policies aimed at benefiting the minority whites against most blacks.

As a pariah state, xenophobia (which refers to the fear or hatred of foreigners or strangers, is embodied in discriminatory attitudes and behavior and often concludes in abuse and violence) in South Africa was mainly expressed through the form of hostile immigration policies that centered for white laborers and limited black individuals. However, after years of apartheid rule, the paradigm shift from pariah to democracy after years of negotiations brought immense opportunities for other African migrants to settle in South Africa. Intending to divert the imbalances of apartheid, Nelson Mandela led the African National Congress (ANC) government that had to deal with rising domestic issues of inequality, unemployment, and poverty (Mlambo, 2019). With Pretoria gradually re-integrating herself in both continental and international landscape, the country witnessed an influx of foreigners to its shores that made for a hostile relationship between South Africans and foreigners. The former often took out their social ills on the latter. Over the years, the South Africans divided locals and immigrants over what Magwaza and Ntini (2020) referred to as a competition for limited resources. Indeed, a plethora of apartheid policies has still not been addressed sufficiently. Within scholarly circles, xenophobia in South Africa rests upon negative perceptions, distrust, suspicion, fear, and national superiority, among other prevailing factors.

Ukwandu (2017) and Statistics South Africa (2020) submitted that it is evident that, despite the end of apartheid, economic apartheid, millions of black South Africans still suffer from immense social ills as the social, economic, and political injustices of decades of segregation, colonialism, and apartheid had devastating development effects. Since the celebrated entry of South Africa into the African democratic space, the resultant implications have been what International Relations (IR) scholars Ogunnubi and Isike (2015) called a change in the contours of power and leadership equalities in Africa. Despite a rich literature on xenophobia in Africa, a dearth of literature exists from an Afrocentric perspective on a comparative study on the nexus on South Africa's post-1994 hegemonic stance and recurring xenophobic attacks. A skim reading of numerous literatures reveals limited engagement on the nexus of hegemonic power and xenophobia.

Therefore, this article brings to the fore the prospect of offering a more robust and nuanced assessment of South Africa's current hegemony in the African context based on its xenophobia conundrum. This article ponders the challenge of xenophobia in post-democratic South Africa and what adverse effect(s) this has had in its continental hegemonic stance. While Pretoria enjoys robust continental and international respect, its prevailing internal problems and ongoing xenophobic attacks on foreign nationals have hampered its continental hegemonic standpoint with other African states since the Mandela administration.

\section{Forced Hegemony: The Apartheid Era and South Africa as a Pariah State}

Various scholars have agreed that South Africa is generally a violent society, and it is important to own up to it to deal with reality. South Africa's culture of violence is deeply entrenched in its violence of colonialism and especially apartheid (Chenzi, 2020; Gumede, 2015). According to the Centre for Human Rights in Pretoria (2009), the development of xenophobia has been a consequence of eradicating the apartheid system in South Africa. The country is one of the most diverse societies globally, but different communities are often very intolerant of others. This is particularly true for African nationals. The legacy of apartheid has 
not only left a profound legacy of black-against-white-racism but has also created a divided society among the different ethnic groups (black-on-black racism) within the country (Gumede, 2015).

To understand South Africa's high levels of crime and violence, these must be analyzed within the context that they occur. Although violence is a global phenomenon, South Africa is dealing with complex and unique dynamics surrounding violence. The country comes from a past riddled with violence and oppression, mainly due to the legacy of apartheid that profoundly impacted how the population navigates its socio-economic, demographic, and geographic areas. According to Mills (1992), South Africa lives in a world built on racial contract stimulated by its colonial history, constitutions, exclusionary practices, juridical mechanisms, history of racist ideologies, and battles against slavery.

These are still fresh in the minds of most post-colonial societies in Africa. Since its formation as the Union of South Africa in 1910, South Africa has been a deeply divided society for more than a century where discrimination, legalized apartheid, racism, and exclusion have been firmly established in its political and social fabric. Indeed, successive heads of states entrenched racist ideologies, and when the National Party (NP) came into power in 1948, apartheid became the official government policy (Muchiri, 2016). Mlambo (2020) notes that the apartheid system was a form of forced hegemony spearheaded by hard power ${ }^{3}$ tactics before the democratic era introduced by the NP and comprised segregation and racial discrimination. In sum, it favored white supremacy over all other races. Because of the racial policies introduced at that time, the NP banned most political parties, including the ANC and other liberation movements opposed to apartheid were banned from South Africa.

During this apartheid era, the international community showed its rejection of apartheid by boycotting South Africa in various spheres encompassing economic and consumer boycotts. These made South Africa further isolated from global politics, which, apart from its economic hardships, was welcomed by the ANC (Lowenberg \& Kaempfer, 1998). Colonialism had a robust link to apartheid during the 1990s. Matsinhe (2011) submits that during this period in South Africa, one was born into. Because of a colonizing figuration constituted through the everyday comings and goings of colonialism, one was born a colonial birth, lived a colonial life, and died a colonial death. Matsinhe further posits that the dislike of blacks and foreign nationals in South Africa extended to a lesser and greater degree, some South Africans, their social relations, their attitudes towards life, their interdependencies, their habits, their personality structure, their beliefs, their stances, and their emotions bear and are a direct result of colonial and apartheid relations. Certainly, from an Afrocentric standpoint, South Africa is exclusive in that it is the place where the doctrine of white hegemony was precisely organized and executed by the white minority for more than five decades.

Drawing from the above sentiments, it may put to the fore that both colonialism and apartheid were enshrined to most individuals during this period, predominantly to most whites and to a degree to some black individuals. Through the transition period to the post-democratic era, it became customary to classify certain individuals through norms and beliefs. Perhaps the point that Peters (2004) made links to the nuanced argument that Matsinhe made that the apartheid groundwork had been laid at the beginning in 1910. To Matsinhe, this is when the British Colonies of Cape and Natal were united with the Afrikaner republics of Transvaal and Orange Free State to form the Union of South Africa. This Union resulted in what he calls a virtual monopoly of political power by English and Afrikaans-speaking whites, thereby marginalizing the majority black population. Another noteworthy explanation that situated xenophobia in the apartheid era were social institutions such as the media that often-produced negative representations not only of blacks but Africa as a whole and African foreigner.

\footnotetext{
${ }^{3}$ Pertains to the use of military and other economic means to influence the behaviour of others. This form of power is normally driven by aggressive means.
} 
These, like today, are congruent with most individual's criminalization of black individuals and African foreign nationals, in particular as illegal people, criminals, drug traffickers, and so forth. During apartheid, strict laws concerning the movement of individuals in the country further limited the ability of South Africans to mix, accommodate or tolerate differences among themselves and between themselves and foreigners (Muchiri, 2016). Misago et al. (2009) attributed some present-day cultures of communal violence and xenophobia to apartheid racist policies. They wrote:

\begin{abstract}
During the apartheid era, the threat of violence, whether "vertical" (state against citizens or "horizontal" (citizens or rival political and social factions against each other) saturated the lives of South Africans residing in the volatile, tightly policed townships. The effects of this historical fabric can be seen in the recent attacks when violence was justified by the references to the politics of housing and employment allocation as well as defending access to "our women" and where criminal opportunism in some cases masqueraded under the evidently more acceptable guise of anti-foreigner initiatives (p. 10).
\end{abstract}

Therefore, during apartheid, South Africa drove its control for power through its hegemonic stance, particularly to its neighboring states. This is notwithstanding the fact that hegemony may be established without the recourse to domination, unilateralism, or military adventurism. However, apartheid-driven South Africa attempted to assert a dominant leadership role in Southern Africa centered on economic power as an instrument for coercion to implement its hegemonic standpoint. Gramsci (1971) stressed that a state could not sustain its power over a long period by coercion alone but had to achieve widespread hegemony. Hence, to gauge the significance of Gramsci's thought on hegemony to South Africa, a noteworthy point of departure would be when the NP came into power in 1948. To Gramsci, a state that does not enjoy widespread hegemony will resort to coercive measures to maintain its power. Indeed, Gramsci's point may be attributed to the NP government that typically utilized force to protect the interests of the minority and enacting numerous laws to spearhead its hegemony.

\title{
From Exile to Partner: South Africa's Distinguished Political Transition (1990-1994) and Re-Entry into Inter-State Relations
}

South Africa's successful negotiated transition from apartheid to democracy is one of the most significant periods in its contemporary historical trajectory. Scholarly studies on democratic transition have made it clear that successful democratization is mostly dependent upon economic development; hence, impediments to economic development are obstacles to expanding democracy (see Welsh, 1994). Right after the Sharpeville Massacre in March 1960, the NP government banned the ANC, forcing it to wage its struggle from exile. Despite a plethora of hardships during exile, the ANC rose to continental prominence in the late 1980s. Its core support structure in its rise was sourced from the Soviet Union, the Socialist Bloc, and independent Southern African States (Graham, 2012). Notably, the ANC possessed immense support, a high level of organization, and mobilization through trade unions, civic groups, and political fronts while enjoying significant international support, making the country ungovernable. According to Nathan (2004), the demise of the cold war introduced other critical dynamics. The Soviet Union was breaking up and could no longer provide arms and military training to the ANC. The United States also began to withdraw from its involvement in wars in Southern Africa; thus, Pretoria could not depend on it for support. Adding to this and because of many sanctions, the economy was in trouble. 
Significant events in the 1980s preceded the end of white domination, encompassing the effective protests of apartheid laws by the black population, pressure from the international community, and the initiation of political transformation by Pieter W. Botha. As the 1990s approached, the international arena and Africa in particular eagerly anticipated Pretoria's muchawaited road to transition. Maharaj (2008) helped identify other significant events that led to the transition negotiations, according to him, these include:

1. The textile workers strike in Durban in 1973;

2. The assassination of Steve Biko in 1977;

3. The 1976 Soweto uprising;

4. The formation of the United Democratic Front (UDM) in 1983 which lobbied other groups to dismantle apartheid;

5. The formation of the Congress of South African Trade Unions (COSATU), which aligned most trade unions into the anti-apartheid stance;

6. The role played by the South Africa Council of Churches; and

7. The Institute of Contextual Theology.

It was in the 1990s that president F.W de Klerk and Nelson Mandela arranged a multiparty negotiation forum. While the ANC and the NP were the main political parties in the transition dialogue, other third parties such as the Inkatha Freedom Party (IFP) and societal organizations such as the Nederduitse Gereformeerde Kerk (NGK), also known as the Dutch Reformed Church (DRC) also had an important role to play in the transition negotiations. According to Graham (2012), the ANC entered the transition period, not knowing anything about foreign policy. It had by 1990 only created three documents relating to foreign policy. These were 1) the Freedom Charter of 1955, 2) the Final Report of the Commission on Foreign Policy from the Kabwe Conference of 1985, and 3) the Harare declaration signed in 1989. These documents were hardly an adequate basis for the foreign policy of a liberation movement nor an aspiring governing political party. In 1990 at parliament, De Klerk announced unprecedented reforms in South Africa; he formally legalized 61 organizations, including the ANC, the South African Communist Party (SACP), and the Pan African Congress (PAC). These were core drivers that provided immense means to dismantle the apartheid regime. These came about through protests, support from both continental and international countries.

After his release from prison, Mandela and de Klerk signed what was known as the Groote Schuur Accord ${ }^{4}$ that gave a path for the peace negotiations to start. These took place from the 1990s through the Convention for a Democratic South Africa $\left(C_{\text {CODESA }}^{5}\right.$ ) made up of multiple political groups; however, negotiations were not as easy and later hit a brick wall. However, Nathan (2004) notes that all leaders at the negotiating table, while determined to advance the interests of their respective organizations, understood the vital importance of forging a settlement that served the national interest. Nevertheless, the transition period was also marred by immense political violence. Many areas throughout South Africa experienced regular fighting, which was often attributed to the NP's determination to weaken the ANC before the 1994 elections (Kynoch, 2013).

\footnotetext{
${ }^{4}$ Is when the ANC and NP made a common commitment towards the resolution of existing climate of violence and intimidation as well as the commitment to stability and for a peaceful process of negotiations. It was followed by the Pretoria Minute where the two parties re-assured their pledge to the Groote Schuur Minute and when the ANC pledged to suspend its armed struggle.

${ }^{5}$ The negotiations went through two stages of CODESA and later the Multiparty Negotiating Process (MPNP). The last and final stage was the formation of the Transitional Executive Council (TEC) in November 1993 that acted as a de facto government and through party consensus governed South Africa until the 1994 elections (Graham, 2012).
} 
Welsh (1994) submits that in de Klerk's mind, he had hoped that the NP's government tenure would enable it to determine the pace and scope of the transition, ensuring the minority whites remain protected in a new political system, while many in the ANC wanted to see a change in power. After other negotiations between the ANC, NP, and other parties, negotiations resumed in 1993 amid a tense situation because of Chris Hani's assassination, the SACP leader. Major setbacks were still being encountered as the NP desired a multi-racial state promising group rights within a capitalist economy. On the other hand, the ANC envisioned a non-racial democracy with a mixed economy. After these negotiations concluded, South Africans found themselves voting in their first ever-democratic elections, thus giving the ANC democratic rights to govern the country (Kuperus, 1996). Of the estimated 22.5 million voters, making a percentage of over $86 \%$, the ANC won $62.6 \%$ of the voters, giving it 252 seats in the 400 hundred National Assembly. The NP won $20.4 \%$ and 82 seats in the National Assembly.

\section{Evolving Trends of Xenophobia in South Africa Post the Democratic Era: A United Africa Deterred}

In the modern contemporary era where the world is increasingly becoming a global village and globalization transcends national boundaries, the inflow and migration of individuals have increased. Post-1994 (as in the apartheid era), South Africa emerged as a regional power with a robust economy, making it one of the most sought-after countries in the continent (Mlambo, 2018). However, post the democratic era, South Africa has had the reputation of being one of the world's most hostile countries when it comes to hosting foreign nationals, particularly from other African countries. According to Mosselson (2010) and Weda $\&$ de Villiers (2019), South Africa has always been a migrant-receiving country, and this trend rose significantly in the post-apartheid era. This trend is usually driven by push factors such as economic hardship, political instability, famine, unemployment, and pull factors such as better living conditions, healthcare, and political stability. For many politicians in the negotiating period, the possibility that the end of apartheid would lead to a significant movement of individuals from other African countries to South Africa was already on their minds (Vale, 2002).

Defining post-apartheid South Africa has been argumentative. A few years after attaining democracy, there has been what Beetar (2018) called a stable status quo for national (un)belonging being portrayed to Africans from elsewhere in the continent. This has often taken place in the form of legislative, discursive, social, and physical violence painting a dark picture that South Africa has become xenophobic and Mandela's dream of a rainbow nation for all tarnished. Incorporating its diverse cultures, traditions, and eleven official languages have given it the title "rainbow nation." Politicians and civil society hold this concept as a crucial allembracing ideal, which claims to encapsulate the inclusiveness of post-apartheid South Africa. However, although seen as an inclusive entity that respects human rights and equality, postapartheid South Africa rests on the foundation of exclusion and removing human rights from particular groups of people (Mosselson, 2010). Hence, it is somewhat ironic that many South Africans, particularly individuals from the ANC and other liberation movements, were welcomed with open arms in neighboring countries when they were banned by the NP (Dodson, 2010). Being South African is now endorsed on a discriminating basis, nationals versus those seen as foreigners. The change from apartheid to democracy was signaled internationally as a miracle transition, and the new administration was to address the country's legacy of the racial divide.

Nevertheless, discriminating attitudes and practices continue to manifest themselves in new forms of identity-based violence: xenophobia. While xenophobia is described as something of a global phenomenon closely linked with globalization, what is prevalent is that it is predominantly common or witnessed in countries undergoing transition. South Africa prides 
itself on having one of the most progressive constitutions ${ }^{6}$ in the world. The Bill of Rights guarantees a host of fundamental political, cultural, and socio-economic rights for all citizens irrespective of race or country, and South African courts have made sure that the fundamental constitutional rights of citizens are protected over the years (Crush, 2000). Like born and bredSouth Africans, migrants from other African countries enjoyed limited rights and protection during the apartheid era. Therefore, why does it seem that this is still the case in post-1994 South Africa?

To address this, Crush (2000) believes that the Mandela-led administration was unprepared for the consequences of Pretoria's re-integration into continental and global politics and the influx of migrants to the country. What served as the core principles in the nationbuilding process post-1994 and is still presently viewed as the cornerstone of South Africa's constitution that Pretoria belongs to all who live in has proved problematic. Xenophobic attacks often occur because of three factors:

1. Interactive factors related to the number of exposure inhabitants have to strangers;

2. Cultural factors which include identity and nationalism; and

3. The material of economic factors related to employment opportunities, available resources, and so forth.

Similarly, South Africans have two fundamental attitudes towards foreigners. They either look up to them as articulate or accomplished or look down on them as stuttering and depleting and that those suffering should instead remain in their home countries and sort out their problems (see Nyamnjoh, 2010). Everatt (2011) and Nwosu and Oyenubi (2021) argue that immense combinations encompassing deep structured social, economic, and spatial inequalities, reliance on cheap labor, shortages in housing, retail competition in townships, racism, a history of violence, and inequality are just some of the essential contributing factors to xenophobia in post-apartheid South Africa. Tella (2016) rightfully notes that, while the state and the international system may play a vital role in combating xenophobia, often individuals such as government officials, traditional leaders, and particularly ordinary citizens exhibit xenophobic attitudes, express xenophobic statements and embark on xenophobic attacks. Post1994, South Africa was painted as a rainbow nation with basic human rights embedded in its Bill of Rights, where there is a great emphasis on how South Africa belongs to all who live in it, regardless of their nationality, race, or gender. According to Vahed (2013), upon its gates being opened to people from other parts of the world, people had certain expectations. However, their experiences during their stay in South Africa tend to contradict the initial perception of this beautiful rainbow nation.

\section{Xenophobia and its Ramifications on South Africa's Continental Hegemonic Power}

In the last decade, the importance of regional powers within their respective neighborhoods has become a prolific academic topic amid the growing multipolarity of the international system (Mesquita \& Seabra, 2020). Because of globalization and other social ills, current global contemporary politics require states to work with each other like never before. This is particularly very relevant to the developing world. Drawing from the above viewpoint, African states are still very much behind concerning development and economic growth. This has put states such as Nigeria and South Africa to be at the fore of Africa's development blueprints. While South Africa's hegemonic posture has been of importance in the last two

\footnotetext{
${ }^{6}$ The new constitution asserted a new sense of belonging to the country, one that is not based on racial or ethnic criteria but, rather, on a collective belonging to the nation that was to be built, and everybody in the country was to have access to the same rights (Hayem, 2013).
} 
decades, how has xenophobia derailed its Afrocentric standing, and, perhaps more importantly, how has this affected its relationship with other African states post democratization?

There is an assumption implied in the literature that post-apartheid South Africa (as Africa's big brother) should have transformed how South Africans treat and perceive foreign nationals. Similarly, in the first few years post the democratic era, the economy and hegemonic posture of South Africa was mainly driven by South Africans themselves. However, Mlambo (2017) believes that as South African businesses made major inroads in most African countries, foreigners started contributing extensively to South Africa's Gross Domestic Product (GDP). It is no hidden fact that South Africa lacks individuals with critical skills and, in most cases, relies on individuals from other countries to enhance its academic, medical, legal, engineering, business, and scarce skills sectors. Therefore, ongoing xenophobic attacks may also deter African individuals from coming and contributing to the economy. From this viewpoint, Abdi (2011), in discussing the ongoing xenophobia attacks against migrants, says, "these stand as a sad reflection of the inability of South Africans to acknowledge the contribution and inevitability of foreigners in the new South Africa" (p. 693).

In sharing the same sentiments with this scholar, this article argues that while some foreigners are in South Africa for bad intentions (just like in any other country), a significant percentage of them, including those who are educated and scattered at other public and private sectors, contribute to the country's GDP and Value Added Tax (VAT). Most small businesses around the country buy straight from South African suppliers; hence, to these migrants and against the backdrop of ongoing xenophobic attacks, serious implications occur, including the loss of income, violation of human rights, displacement, and even death. These have severe consequences for the outlook on South Africa's constitution and its emphasis and recognition of the fundamental human rights of all who live in it. In this vein, a noteworthy point of departure is how these attacks affect Pretoria's continental agenda with other African states.

Over the years, most African heads of states have condemned the spate of attacks on their nationals. As a big brother, South Africa has portrayed its continental hegemonic posture and effectively exercised leadership roles on behalf of the continent. Its inclusion among BRICS countries) Brazil, Russia, India, China, South Africa) and the Group of 20 further provides a geographical representation of Africa in these institutions. Mabera (2017) noted that Pretoria was at the forefront in establishing and funding institutions in Africa to contribute to a peaceful and prosperous Africa. These include the New Partnership for Africa's Development (NEPAD), the African Peer Review Mechanism (APRM), the Southern African Development Community (SADC) as well as other peace institutions such as the African Peace and Security Architecture (APSA) and the Africa Capacity for Immediate Response to Crises (ACIRC) while also initiating the African Renaissance Fund (ARF) in 2004.

Similarly, Madise and Isike (2020) note that this extension of political goodwill is an effort to regain trust and solidarity with its neighboring states and further demonstrate its commitment to the continent's development. South Africa has vast global personalities scattered within sports, education, music, and so forth. These individuals stimulate followers globally, further boosting Pretoria's attractions in Africa and globally, thus building South Africa's positive image. Again, Tella and Ogunnubi (2014) put to the table that a significant source of Pretoria's soft power ${ }^{7}$ is driven by its political values, which encompass, among other things, its liberal democracy, human rights culture, and progressive constitution.

However, the on-going xenophobia attacks have tarnished both its continental and global image and condensed its soft power currencies in Africa. It has also resulted in a diplomatic cold war, particularly with Africa's biggest economy in Nigeria. Given that these two are the so-called big boys in the continent, this brings serious ramifications in Africa's quest for tangible regional integration. As mentioned earlier, various South African businesses

\footnotetext{
${ }^{7}$ In IR, this is a persuasive approach that involves the use of economic and cultural influence.
} 
are scattered across various sectors, such as telecommunications, mining, agriculture, construction, and hospitality. These businesses further show South Africa's influence in Africa, and these businesses create employment opportunities where they are based. They further entice foreign direct investment to South Africa, and every country is aware of the importance of foreign direct investment to its economies to boost economic growth. When xenophobia persists in South Africa, businesses in these countries are often attacked, which further derails African integration and presents a threat to economic growth (Bello \& Tunde, 2017). As Tella and Ogunnubi (2014) posit, a regional power ought to be tolerant to all individuals from anywhere in the world; however, this seems to be not the same with South Africa. Its poor tolerance of other African nationals further dents its chance of regional acceptance and further paints a dark picture of other African states' legitimacy and recognition to act as a regional and continental hegemon.

Drawing from the above, xenophobic challenges expose the conspicuous need for selfexamination of South Africa's foreign policy and, importantly, its African agenda. If the government continues to take this lightly, the outcomes will prove harmful to Pretoria's development partnership agenda. Important South Africa blueprint projects such as the White Paper on South Africa's foreign policy and the New Growth Plan, and the National Development Plan (NDP) affirm that regional integration is an essential doctrine in Pretoria's African outlook, which has been the core in many blueprints for more than two decades. While its African hegemonic stance has been questioned over the years and not accepted by some, we postulate that another pandemic in xenophobia will further add to its legitimacy been questioned by fellow African states. In sum, South Africa is still regarded as possessing the best economy in Africa and is well respected by some continentally and abroad due to its hegemonic power and spearheading the African regional integration agenda. However, this has been dented in recent years because of its shrinking economy and recurring xenophobia. While since the Mandela administration South Africa has tried to put into practice the much-publicized core pillars that encompass, among others, promoting human rights, democracy, justice, and respect for international law. Over the years, a mostly vague foreign policy outlook in which the premium of human rights and democracy often incurred in initiatives that either contradicted some of its tenets or underscored the limits of its continental appeal (Mesquita \& Seabra, 2020). Therefore, if Pretoria is to bring back the respect it once enjoyed from the Mandela administration, one may ask what could be the way forward and what possible solutions may be brought forward.

\section{Conclusion and Possible Recommendations}

This article aimed to ponder the continuous xenophobic attacks in post-democratization South Africa and its effect on its African hegemonic posture. It intended to put to the fore the prospect of offering a more robust and nuanced assessment of South Africa's current hegemony in the African context based on its xenophobia conundrum by pondering the challenge of xenophobia in post-democratic South Africa and what adverse effect(s) this has had in its continental hegemonic stance. This was drawn from the fact that previous studies (see Gordon, 2018; Moagi et al, 2018; Obadire, 2018; Steenkamp, 2009) only focused on xenophobia from a South African perspective and no authors have linked the nexus of xenophobia and Pretoria's hegemonic stance in Africa since the end of apartheid. The article shows that the broader implications of xenophobia in Africa and South Africa in particular is that after 27 years since the inauguration of the Mandela led administration, South Africa is still a country in transition, largely because of the imbalances of apartheid and current socio-economic ills.

It rightfully shows that Pretoria is still regarded as Africa's powerhouse; however, the prevailing and continuous xenophobic attacks tend to paint a bad picture from its continental 
hegemonic standpoint. In particular, Pretoria's role in Africa and Southern Africa is still marked by a profound historical legacy and the corresponding political will to surpass it. Following years as a pariah state, 1994 witnessed what Mesquita and Seabra (2020) call a wholesome effort to push beyond the apartheid stigma and win over new external credentials. It is not much of an obvious implication to say Pretoria's democratic prospects will depend on its ability to shake off the legacy of years of inequality, poverty, and unemployment.

Other massive backlogs still exist in housing, education, health, and the provision of basic services like sanitation, water, and electricity. The lack of an exact and corresponding policy implementation has meant that many individuals have not had proper preparation for the influx of migrants into their communities, which has had dire effects through xenophobic violence over the years (Adeola, 2015). Naidu et al. (2015) made an excellent point when they argued that the government must pay urgent attention to address the plethora of current social ills such as unemployment, inequality, and immense corruption by municipalities and government departments responsible for the provision of basic services. Political will and continual and coordinated interventions are needed to address the challenge of xenophobia.

Miller (2018) argued that a lack of progress in combating xenophobia can be primarily explained by people's unwillingness to admit that they have a problem. For this reason, Masikane et al. (2020) submitted that the leadership response shapes the public opinion of xenophobia and the further denial by the leadership that xenophobia exists shapes people's mindsets to think that it is the right thing to do. Ironically, over the years, the South African government has not taken the attacks seriously. To it, these attacks are just an act of criminality. This undeniably undermines the fundamental human rights of individuals. To resolve this issue, the AU and the SADC should institute programs to hold the government accountable. As a robust civil society state, these programs and accountability structures could build on the ones that civil societies have already developed. Unlike other African countries where civil society plays a small role in lobbying for better policies, it plays a robust part in taking government into account in South Africa. Hence, civil society could actively (which some have been doing) lobby the state to develop robust anti-xenophobic policies coupled with tangible monitoring and evaluation frameworks (see Mlambo, 2020).

Perhaps another vital element will be a detailed plan of action and legislation and provisions to disallow direct and indirect discrimination based on actual or presumed nationality or national origin. This should guarantee effective legal, managerial, and other robust remedies for non-South Africans and encompassing not only the government but also other pivotal role players such as the private sector, civil society, and concerned citizens. If South Africa is to continue spearheading regional integration, government departments, especially the Department of Home Affairs, should join the party with robust and tangible policy guidelines for immigrants (Kanayo et al., 2019).

A need exists for local councilors and individuals who represent the people at the local level to be trained with robust knowledge or people management and intervention mechanisms to deal with xenophobic violence. There ought to be better policies in a similar vein, particularly to the youth, to address the challenge of xenophobia. This curriculum should draw insights into colonialism's effects on Africa's development, resource management, and aspects of terrorism, coup d'états, political instability, critical skills, and push and pull factors. This will lay a foundation for why people move from one place to another and for what reasons. Perhaps if tomorrow's future leaders and policymakers are given such fundamental push and pull backgrounds at a younger age, xenophobia, just like colonialism and apartheid, would be a thing of the past.

The role of regional and continental institutions to advance cooperation among African states is of paramount importance. Indeed, the SADC and the AU can play a significant role in assisting the South African government in coming up with more stringent xenophobia policies. As Adeola (2015) noted, the AU Constitutive Act is mandated to promote human rights, the 
sanctity of life, and peaceful co-existence and cooperation between African states. As South Africa, through its Bill of rights, rightfully commits to protect various civil, political, and socioeconomic rights for everyone living and working in South Africa, the government needs to start putting money where its mouth is and draw from these rights. While the concept of $U_{b u n t u^{8}}$ is always in government speeches, South Africa has genuinely not respected this concept over the years. All South Africans should understand the concept of Ubuntu as a way of respecting each other and alleviating xenophobia. Since the initial eruption of xenophobia in South Africa post1994, the government has not accepted that South Africans are generally xenophobic and xenophobic; hence, it is challenging to solve something when its existence is denied. The government should ensure that it adheres to its obligations regarding protecting refugees and asylum seekers' rights in the country. Currently, South Africa does not have a specific law to address xenophobia and other hate crimes. Given the country's history of apartheid, racial discrimination, and the persistence of xenophobic violence, it is a form of negligence for the country not to have laws concerning xenophobic or hate crimes.

A clear government policy that aligns with international refugee standards should be implemented (Gurer, 2019). The government should enforce a monitoring and evaluation mechanism on policy compliance across local, provincial, and national strata. Public officials should be monitored and evaluated in the workplace to determine if they still adhere to the Batho Pele principles (service standards, access, courtesy, information, openness and transparency, redress, and value for money), which are in every official's handbook and guide them in carrying out their duties and rendering services to the general public who are their clients. The results of these monitoring and evaluation processes should be reported and laggards duly punished.

The South African government needs to educate its people on the importance of human rights preservation of all those living in the country and the different categories of foreign nationals, their rights, and their obligations in South Africa. This will influence and possibly change locals' views about foreign nationals being invaders of privacy and threats to their social development. Having social cohesion programs and izimbizo will be an excellent platform for people to meet and speak with the government on issues revolving around xenophobia and people's need to be educated on such matters.

South Africa's youth should be duly used in these drives as they are the country's future. A fundamental point that Madise and Isike (2020) make is that if South Africa continues to demand regional leadership, it must be from the African continent's inhabitants themselves. This will require consistency in its foreign policy guided by the notion of Ubuntu. For this to be realized, the government must first uplift its citizens and reduce competition among citizens with African nationals over basic needs. Some of these recommendations are far from inclusive. However, they lay a solid foundation for further research and inputs, and there are no guarantees that the mechanisms outlined above will prevent future xenophobic violence. However, they might assist in reducing such incidents moving forward.

\footnotetext{
${ }^{8}$ Ubuntu pertains to an African philosophy that emphasizes the recognition of common humanity among the people of Africa and has its origins across Africa mostly in the Southern and Eastern parts of the continent (Madise \& Isike, 2020).
} 


\section{References}

Abdi, C. M. (2011). Moving beyond xenophobia: Structural violence, conflict and encounters with the 'other' Africans. Development Southern Africa, 28(5), 692-704. https://doi.org/10.1080/0376835X.2011.623916

Adeola, R. (2015). Preventing xenophobia in Africa: What must the African Union do? AHMR, 1(3), 253-272.

Beetar, M. (2018). A contextualization of the 2008 and 2015 xenophobic attacks: Tracing South $\begin{array}{llll}\text { African } & \text { necropolitics. }\end{array}$ https://doi.org/10.1177/0011392118807528

Bello, I., \& Tunde, S. R. (2017). The implications of xenophobic violence on Nigeria-South Africa relations. Journal of International Studies, 13, 117-125. https://doi.org/10.32890/jis2017.13.8

Centre for Human Rights. (2009). The nature of South Africa's legal obligations to combat xenophobia. Pretoria: The Centre for Human Rights. Retrieved January 14, 2021, from https://www.chr.up.ac.za/images/publications/centrepublications/documents/south_afr ica_legal_obligations_combat_xenophobia.pdf

Charman, A., \& Piper, L. (2012). Xenophobia, criminality and violent entrepreneurship: Violence against Somali shopkeepers in Delft South, Cape Town, South Africa. South African Review of Sociology, 43(3), 81-105. https://doi.org/10.1080/21528586. 2012.727550

Chenzi, V. (2020). Fake news, social media and xenophobia in South Africa. African Identities. 1-20. https://doi.org/10.1080/14725843.2020.1804321

Crush, J. (2000). The dark side of democracy: Migration, xenophobia and human rights in South Africa. International Migration, 38(6), 104-133. https://doi.org/10.1111/14682435.00145

Dodson, B. (2010). Locating xenophobia: Debate, discourse and everyday experience in Cape Town, South Africa. Africa Today, 6(3), 2-22 https://doi.org/10.2979/aft.2010.56.3.2

Everatt, D. (2011). Xenophobia, state and society in South Africa. Politikon: South African Journal of Political Science, 38(1), 7-36. https://doi.org/10.1080/02589346. 2011.548662

Gurer, C. (2019). Refugee Perspectives on Integration in Germany. American Journal of Qualitative Research, 3(2), 52-70. https://doi.org/10.29333/ajqr/6433

Gordon, S. (2018). Who is welcoming who and who is not? Attitudinal analysis of antiimmigrant sentiment in South Africa. South Africa Review of Sociology, 49(1), 72-90, https://doi.org/10.1080/21528586.2018.1475252

Graham, M. (2012). Foreign policy in transition: The ANC's search for a foreign policy direction during South Africa's transition 1990-1994. The Round Table, 101(5), 405423. https://doi.org/10.1080/00358533.2012.713231

Gramsci, A. (1971). Selections from prison notebooks. International Publishers.

Gumede, W. (2015, April 20). South Africa must confront the roots of its xenophobic violence. The Guardian. https://www.theguardian.com/commentisfree/2015/apr/20/south-africaxenophobic-violence-migrant-workers-apartheid

Hayem, J. (2013). From May 2008 to 2011: Xenophobia violence and national subjectivity in South Africa. Journal of Southern African Studies, 39(1), 77-97. https://doi.org/10.1080/03057070.2013.767538

Kanayo, O., Anjofui, P., \& Stiegler, N. (2019). Analysis of ramifications of migration and xenophobia in Africa: Review of economic potentials, skills of migrants and related policies in South Africa. Journal of African Union Studies, 6(2), 65-85. https://doi.org/10.31920/2056-5658/2019/6n3a4 
Kuperus, T. (1996). Resisting or embracing reform? South Africa's democratic transition and NGK-State relations. Journal of Church \& State, 38(4), 841-872. https://doi.org/10.1093/jcs/38.4.841

Kynoch, G. (2013). Reassessing transition violence: Voices from South Africa's township wars 1990-4. African Affairs, 112(447), 283-303. https://doi.org/10.1093/afraf/adt014

Lowenberg, A. D., \& Kaempfer, W. H. (1998). The origins and demise of South African apartheid: A public choice analysis. The University of Michigan Press.

Mabera, F. (2017). The impact of xenophobia and xenophobic violence on South Africa's development partnership agenda. Africa Review, 9(1), 28-42. https://doi.org/10.1080/09744053.2016.1239711

Madise, D., \& Isike, C. (2020). Ubuntu diplomacy: Broadening soft power in an African context. Journal of Public Affairs, 20(2), 1-10. https://doi.org/10.1002/pa.2097

Magwaza, S., \& Ntini, E. (2020). Causes of xenophobic violence in UMlazi suburb-perceptions of a migrant family. African Journal of Development Studies, 10(2), 27-57. https://doi.org/10.31920/2634-3649/2020/10n2a2

Maharaj, M. (2008). The ANC and South Africa's negotiated transition to democracy and peace. Bergohf Foundation. https://www.berghoffoundation.org/fileadmin/redaktion/Publications/Papers/Transitions_Series/transitions _anc.pdf

Masikane, C. M., Lewit, M. C., \& Toendephi, J. (2020). Dynamics informing xenophobia and leadership response in South Africa. Acta Commercii: Independent Research Journal in Management Sciences, 20(1), 1-11. http://dx.doi.org/10.4102/ac.v20i1.704

Matsinhe, D. M. (2011). Africa's fear of itself: The ideology of Makwerekwere in South Africa. Third World Quarterly, 32(2), 295-313. https://doi.org/10.1080/01436597.2011.560470

Mesquita, R., \& Seabra, P. (2020). Go global or go home: Comparing the regional vs global engagement of Brazil and South Africa at the UN General Assembly. Politikon, 47(3), 361-384. https://doi.org/10.1080/02589346.2020.1796185

Miller, S. D. (2018). Xenophobia towards refugees and other forced migrants [World Refugee Council Research Paper No. 5]. Centre for International Governance Innovation. https://www.cigionline.org/sites/ default/files/documents/WRC\%20Research\%20Paper\%20no.5.pdf

Mills, C. W. (1992). The racial contract. Cornell University Press.

Misago, J. P., Landau, L., \& Monson, T. (2009). Towards tolerance, law and dignity. Addressing violence against foreigners in South Africa. International Organization for Migration. https://www.atlanticphilanthropies.org/wpcontent/uploads/2015/09/IOM_Addressing_Violence_Against_Foreign_Nationals.pdf

Mlambo, D. N. (2017). Regional supremacy or coalition? Evaluating South Africa's regional integration efforts within the Southern African Development Community (SADC) [Master's thesis, University of Zululand].

Mlambo, D. N. (2018). Continental migration trends: Its implications from an African perspective. Journal of Social and Development Sciences, 9(2), 22-27. https://doi.org/10.22610/jsds.v9i2.2378

Mlambo, D. N. (2019). A South African perspective on immigrants and xenophobia in post1994 South Africa. African Renaissance, 16(3), 91-104. https://doi:10.31920/2516$5305 / 2019 / 16$ n 1 a3

Mlambo, D. N. (2020). Reframing the notion of regional integration in Sub-Saharan Africa: What role for civil society. E-Bangi, 17(5), 144-153. https://doi.org/10.31920/25165305/2019/16n1a3

Moagi, M., Wyatt, G., Mokgobi, M., Loeb, T., Zhang, M., \& Davhana-Maselesele, M. (2018). Mozambican immigrants to South Africa: Their xenophobia and discrimination 
experiences. Journal of Psychology in Africa, 28(3), 196-200, https://doi.org/10.1080/14330237.2018.1475485

Mosselson, A. (2010). 'There is no difference between citizens and non-citizens anymore': Violent xenophobia, citizenship and the politics of belonging in post-apartheid South Africa. Journal of Southern African Studies, 36(3), 641-655. https://doi.org/10.1080/03057070.2010.507570

Muchiri, G. R. (2016). Xenophobia: A critical study of the phenomenon and pragmatic solutions for South Africa [Doctoral dissertation, University of Pretoria]. https://repository.up.ac.za/bitstream/handle/2263/56982/Muchiri_Xenophobia_2016.p df? sequence $=1$

Naidu, R., Dippenaar, J., \& Kariuki, P. (2015). When xenophobia rears its ugly head: A challenge to responsible and responsive governance. https://www.kas.de/documents/252038/253252/7_dokument_dok_pdf_43791_2.pdf/af c8fa00-12f5-949a-ff0a-b1dc99f1a548?version $=1.0 \& \mathrm{t}=1539651416218$

Nathan, L. (2004). Accounting for South Africa's successful transition to democracy [Discussion Paper No. 5]. Crisis States Development Research Centre. https://www.lse.ac.uk/international-development/Assets/Documents/PDFs/csrcdiscussion-papers/dp05-Accounting-for-South-Africas-successful-transition-toDemocracy.pdf

Nwosu, C. O., \& Oyenubi, A. (2021). Income -related health inequalities associated with the coronavirus pandemic in South Africa: A decomposition analysis. International Journal of Equity \& Health, 20(1), 1-12, https://doi.org/10.1186/s12939-020-01361-7

Nyamnjoh, F. B. (2010). Racism, ethnicity and the media in Africa. Reflections inspired by studies of xenophobia in Cameroon and South Africa. Africa Spectrum, 45(1), 57-93. https://doi.org/10.1177/000203971004500103

Obadire, O. S. (2018). Towards a sustainable anti-xenophobic rural-based university campus in South Africa. Journal of Higher Education, 32(4), 186-198, http://dx.doi.org/10.20853/32-4-1507

Ogunnubi, O. (2019). Soft power and the currency of sport: Re (imagining) South Africa's rising hegemony in Africa. Global Society, 33(4), 520-540. https://doi.org/10.1080/13600826.2019.1642184

Ogunnubi, O., \& Isike, C. (2015). Regional hegemonic contention and the asymmetry of soft power: A comparative analysis of South Africa and Nigeria. Strategic Review of Southern Africa, 37(1), 152-177.

Peters, W. (2004). Apartheid politics and architecture in South Africa. Social Identities: Journal of the Study of Race, Nation and Culture, 10(4), 537-547. https://doi.org/10.1080/1350463042000258953

Statistics South Africa. (2020). SA Economy Sheds 2.2 million jobs in Q2 but unemployment levels drop. Retrieved March 10, 2021, from, http://www.statssa.gov.za/?p=13633

Steenkamp, C. (2009). Xenophobia in South Africa: What does it say about trust? The Round Table, 98(403), 439-447. https://doi.org/10.1080/00358530903017949

Tella, O. (2016). Understanding xenophobia in South Africa: The individual, the state and the international system. Insight on Africa, 8(2), 142-158. https://doi.org/10.1177/ 0975087816655014

Tella, O., \& Ogunnubi, O. (2014). Hegemony or survival: South Africa's soft power and the challenge of xenophobia. Africa Insight, 44(3), 145-163. https://hdl.handle.net/ 10520/EJC172069

Ukwandu, D. C. (2017). Reflections on xenophobic violence in South Africa: What happens to a dream deferred? African Journal of Public Affairs, 9(9), 43-61.

Vale, P. (2002). Migration, xenophobia and security-making in post-apartheid South Africa. Politikon, 29(1), 7-29. https://doi.org/10.1080/02589340220149416 
Weda, Z., \& de Villiers, R. (2019). Migrant Zimbabwean Teachers in South Africa: Challenging and Rewarding Issues. Journal of International Migration and Integration, 20, 1014-1028, https://doi.org/10.1007/s12134-018-00649-6

Welsh, D. (1994). South Africa's democratic transition. The Brown Journal of World Affairs, 2(1), 221-230. https://www.jstor.org/stable/24595472

\section{Notes on Contributors}

Daniel Nkosinathi Mlambo holds a PhD in Public Administration from the University of Zululand and is a New Generation of Academics Programme (nGAP) lecturer at Tshwane University of Technology (TUT) in the Department of Public Management. His research interests revolve around regional integration in Africa (particularly Southern Africa), Corruption, Governance and Democracy and Migration.

Victor H. Mlambo is a Lecturer at the University of Zululand under the Department of Politics and International Studies. Victor's areas of research include in Migration, Regional Integration and issues of Gender equality and Geopolitics. 